Accepted

20. 10.2020

Revised

1. 11.2020

Published

21. 12.2020

UDC

340.155:364(81)

Keywords rule of

law,

development,

social

injustice,

endemic

violence,

mass

incarceration.

\section{ERODED RULE OF LAW, ENDEMIC VIOLENCE AND SOCIAL INJUSTICE IN BRAZIL}

\author{
Mitja KovaČ \& MARCELA NeVES BEZERRA \\ University of Ljubljana, School of Economics and Business, Ljubljana, Slovenia. \\ E-mail: mitja.kovac@ef.uni-lj.si \\ University of Ljubljana, School of Economics and Business, Ljubljana, Slovenia. \\ E-mail: nevesmarcelab@gmail.com \\ CORRESPONDING AUTHOR \\ mitja.kovac@ef.uni-lj.si
}

Abstract Modern Brazil is plagued by social and economic inequalities, endemic violence, crime, and a weak rule of law. Once these narratives become dependent on each other, all aspects must be worked on to change the scenario the country is facing: insecurity, fear and a lack of opportunities. This paper argues that the unprecedented rise of social injustice in Brazil is not the result of short-term measures but is part of its history marked by economic and social inequalities extending from its colonial past until today and the deficient policies on crime that emerged in the mid-1990s. Moreover, the current massive incarceration, overcrowding of prisons combined with the absence of human living conditions is turning the prison system in Brazil into a gigantic, perpetual school of crime. Investment in education that directly helps to lower the crime rate must be aligned with a new, less repressive and more inclusive punitive policy so as to induce criminals not to return to their unlawful ways. It is suggested that Brazil can only properly develop if efficient legal institutions, the rule of law, and criminal sanctioning based on the principles of social justice are available to all citizens. 


\section{$1 \quad$ Introduction}

It is today abundantly clear that the legal institutional framework matters for longterm growth and sustainable development (North, 1989; Acemoglu and Johnson, 2005; Acemoglu et al., 2002; Acemoglu et al., 2001; Rodríguez-Pose, 2013). Conventional wisdom states that broad-based inclusive property rights and low-cost contracting institutions encourage growth. Societies without a robust rule of law, secure property rights and low transaction costs seldom flourish in the long run. The question of the extent to which legal institutions really matter for growth and sustainable development, and which layers are most crucial for economic growth, remains largely unanswered. Most studies examine the impact of legal institutions on growth and development at the country level. Such studies tend to focus on statistical identification issues and barely shed any light on the relationship between legal institutions and economic development (Helland and Klick, 2011).

Aggregate correlations of various measures of legal institutions and economic growth can, due to the omitted variable bias problem, not provide much evidence on how legal institutions impact growth and sustainable development (Sobel and Coyne, 2011). Such comparisons consider different legal systems and histories and merely show that factors other than legal institutions are related to economic development (Olson, 1984; De Soto, 1989).

The rule of law, as a principle of governance, is also a key to achieving sustainable development. A strong rule of law concentrates on adopting sound and fair laws and policies and assures that states honour their commitments and work towards inclusive and sustainable development (IDLO, 2015; Faure and Smits, 2011). In relation to the specific issue of how legal institutions can limit the implementation of sustainable practices, the literature emphasises that the rule of law is important (Castiglione et al., 2015) along with the EU's sustainable development strategy and associated sustainability reporting practice (Delbard, 2008; Pope et al., 2004). Khan (2018) and Rodrick et al. (2004) suggest that the rule of law plays a critical role in advancing sustainable development, whereas Aseeva (2018) stresses the role of international economic law. In their empirical study, Walker et al. (2008) state that environmental legislation is not a triggering factor in sustainable practices being implemented by firms. Insightfully, Cooter and Schäfer (2012) coin the "double trust dilemma of (sustainable) development" term and argue that sustained growth depends on innovation. Developing such innovation requires financial investment, 
in turn implying the problem of trust. They argue that effective (efficient) legal systems and legal rules help to bring capital and innovation together and thereby boost sustainable development (Cooter and Schäfer, 2012). In addition, in their pathbreaking work Trebilcock and Prado (2011) and Ulen (2011) identify the quality of legal institutions as the main mechanism driving economic development and growth.

This paper joins this scholarly debate and attempts to show that Brazil can only properly develop if efficient legal institutions, the rule of law, and criminal sanctioning based on social justice principles are available to all citizens. Namely, Brazil's history is marked by various periods of exploitation, abuse and violence, from colonial violence through to today's institutional violence. Moreover, the paper addresses the profound discursive changes made in the field of criminal policies, moving from the criminal welfare model (Connolly et al., 2004) to increased punishment and suffering from significant interference by the economic model, modulating mass incarceration driven by private interests that work in the shadows.

Further, this paper describes how social and economic inequality is a phenomenon rooted in the process of political formation in Brazil. The current structural inequality passively observed by the Brazilian state directly affects political decisions made in the public sphere. Public mismanagement, in turn, generates all manner of harm to society and to the democratic rule of law, and is directly linked to the high level of violence and human rights violations. The aim of this paper, therefore, is to show that: a) social inequality as inherited from the colonial past has had deleterious long-term effects and is positively related with the endemic violence in Brazil; b) the punitive system and repressive criminal policies used to combat crime have led to greater violence across the country; and c) the mass incarceration caused by the criminal justice policy in place is also harming the country's economy.

The analysis in this paper is both positive and normative. Moreover, the analytical approach employs interdisciplinary dynamic analysis and enriches it with concepts used in the economic analysis of law (Wittman, 2006; De Geest, 2011; Posner, 2011; Bouckaert and De Geest, 2009; De Geest, 2001).

However, two caveats must be made. The first caveat relates to the scientific authority that should be attributed to our findings. The legal and economic arguments used are, strictly speaking, not a theory but a method for facilitating discussions on the law. The second caveat concerns the scope of this paper. Since it 
is impossible to cover all aspects of the impact of the legal-institutional framework on social and economic inequality, this paper focuses on the narratives of Brazil's punitive and constitutional development.

This article has the following structure. The first part offers a general background and discusses the theoretical mechanisms at work. The second part presents a synthesis of the history of violence and social injustice in Brazil. Part three discusses the notorious political violence, social injustice, and mass incarceration that has transpired in Brazil and their detrimental effects on development. The fourth part investigates the relationship between proper development in Brazil, efficient legal institutions, the rule of law, and criminal sanctioning based on the principles of social justice. The paper concludes with a set of recommendations.

\section{Theoretical mechanisms at work}

\subsection{General literature}

This section details the theoretical framework linking the concepts of the rule of law and social injustice with the economic rationale. Specifically, it links them with the fundamental economic problem of transaction costs and with the various sources of economic growth and sustainable development.

Economists generally construct their growth models on the gains from trade and highlight the roles played by specialisation, the division of labour, capital accumulation, human capital, entrepreneurship and technology as key factors in long-run development patterns. However, while constructing such models they ignore the costs of transacting and their potential impact on economic growth (North, 2005). Still, as Coase (1960), North (1990), Acemoglu et al. (2005) and many other scholars stress, such levels of physical, human capital and technology of societies should be regarded as being endogenously determined by differences in institutional (i.e. legal) incentive streams. The importance and origin of such legal institutions might be embodied by their capacity to generate transaction costs.

The welfare of human society depends on the flow of goods and services, which in turn depends on the productivity of the economic system (Coase, 1998; 1994). Productivity depends on specialisation, which is only possible if there is an exchange of goods and services. Such a voluntary transaction benefits both parties, but 
transaction costs tend to reduce the value of an exchange and both contracting parties will want to minimise them. The amount of exchanges which spur allocative efficiency also depends, as Coase (1988) and North (1990) argue, upon the costs of the exchange ${ }^{1}$ - the lower they are, the more specialisation there will be and the greater the productivity of the system.

From a normative perspective, an efficiency- and welfare-minded policymaker should economise on the transaction costs generated by different legal institutions to spur and enable sustainable development and economic growth. North (2005) also states that "the costliness of information is the key to the costs of transacting, which consist of the costs of measuring the valuable attributes of what is being exchanged and the costs of protecting rights and policing and enforcing agreements". He adds that it is precisely those transaction costs (i.e. the costs of measurement and enforcement) which constitute the sources of social, political and economic institutions.

Recent empirical investigations (North and Wallis, 1986; Masten, Meehan and Snyder, 1991; McCloskey and Klamer, 1995; Dollery and Leong, 1998; Kovač and Spruk, 2016) offer further evidence of the impact/importance of transaction costs for the long-term path of economic growth. Hence, to encourage economic growth the efficiency- and welfare-minded policymaker should economise on the transaction costs created by different legal institutions.

Arrow and Debreu (1954), De Geest (1994), Williamson (1996) and Posner (2011), while closely resembling Coase's concept, insightfully define transaction costs as the costs of running the economic system of exchanges - the costs of exchange. For example, when Robinson Crusoe was alone on the island, there were no transaction costs as soon as Friday arrived and they started to work together, transaction costs arose. Here, one should note that transaction costs are not costs like production costs or precaution costs (which Robinson would also have if one aimed to have the optimal pollution on his island) but simply the costs of economic exchanges. Coase's (1960) definition of transaction costs actually encompasses ex ante costs (before the exchange) associated with the search, negotiation and ex post costs (after exchange) of monitoring and enforcement.

\footnotetext{
1 The costs of exchange actually depend on the institutions in a country: the legal system, political system, social system, education system, the culture etc. (Coase, 1998).
} 
This ground-breaking insight also implies that one of the most important economic functions of the law and of an elaborated legal system is the systematic decrease of transaction costs (mitigation of the notorious problem of positive transaction costs). In other words, in the world of zero transaction costs law and the broad principles of the rule of law will be a trivial consideration and will not be needed for achieving the efficient allocation of resources and for the operation of the system of economic exchanges. However, in the world of positive transaction costs rule of law is a necessary precondition for the sole existence of markets, sequential transactions and for the smooth functioning of the system of economic exchanges. Economically speaking, law might be seen as a sophisticated economic institution that, among other functions, also attempts to mitigate the problem of positive transaction costs. Moreover, markets, trade, economic exchanges and industrial production can seldom flourish in the absence of such a sophisticated legal system and countries suffering from the transaction cost problem are destined to poverty, misery and social injustice.

\subsection{Social justice, development and role of the legal system}

Considerable empirical research on the relationship between legal institutions and development demonstrates that improvements in the legal system's operation are likely to dramatically influence development outcomes. Kaufmann (2004), for example, shows that an improvement in the legal system's operation by one standard deviation from the current levels in the Ukraine to those middling levels found in South Africa would lead to a four-fold increase in per capita income in the long run.

In his ground-breaking work on the beneficial impacts of legal reforms, De Soto argues that "development is possible only if efficient legal institutions are available to all citizens" and regards the law "as the most useful and deliberate instrument of change available to people" (De Soto, 1989). He also sees the different legal systems as the main explanation for the different development patterns existing between industrialised and non-industrialised countries (De Soto, 1989).

Economic literature also suggests that not only is law highly relevant for the development of countries, but that particular legal systems do better than others (Faure and Smits, 2011; Demsetz, 1968). Moreover, Castiglione et al. (2015) in their empirical study reveal a positive double causality relationship between the rule of law and income per capita, whereby as income increases, greater respect for the rule 
of law is acquired, and vice versa. They also suggest that the rule of law (and the quality of legal institutions) has a negative relationship with pollution, confirming that the enforcement of rules is a "conditio sine qua non" for controlling pollution, while the reverse causality that pollution influences the rule of law does not hold (Castiglione et al., 2015).

\subsection{Degraded rule of law as the biggest impediment to inclusive development}

Systematic degradation, decomposition of the rule of law and constant political undermining and complete ignorance of the legal institutions may be the biggest, thus far largely overlooked, threat to the implementation of sustainable practices and development in Brazil.

The idea of the rule of law originated in Aristotle's highly abstract concept of "corrective justice," a theory which Posner (2011 and 2001) describes as a concept itself rich in economic significance. Namely, Aristotle argued that "if someone engages in wrongful behaviour that disturbs the pre-existing balance of wealth or other advantages between himself and another person, to the injury of the latter, that person is entitled to some form of redress that will, to the extent feasible, restore the pre-existing balance, or in other words rectify the departure from equilibrium caused by the wrongful act" (Posner, 2011). This concept of justice "without regarding to persons" is also indispensable to efficiency and wealth maximization (Posner, 2011). John Rawls identified four elements of the "rule of law" concept: a) law must be capable of being complied with by those to whom it is addressed; b) law must treat equally those who are similarly situated with respect to a given legal rule; c) law must be public; and d) law must provide means for determining the truth of any facts necessary to the application of a legal rule (Rawls, 1971). These four elements are also central to the previously discussed transaction cost related economic concept. The primary function of law is to economize on transaction costs. This implies that in the absence of the rule of law transaction costs will be increased exponentially and such an increase will sooner or later materialize in the forms of increased social inequality, injustice, loss of social wealth, poverty and misery. The second function of the law is to alter incentives to achieve socially wealth maximizing behaviour. This also implies that the law does not command the impossible, since a command impossible to fulfil will not alter behaviour (Becker and Posner, 2009; Posner, 2011). Posner (2011) also suggests that the requirement that law must treat equals equally is 
another way of saying that the law must have a rational structure. The more general (i.e. general application) the law is, the more difficult it is for the government to punish dissenters, exploit unpopular individuals, and engage in other abuses (Posner, 2011). The economic theory of law is a theory of deterrence and a threat that is not communicated (requirement that the law must be public) cannot deter. Economic theory also presupposes a machinery for ascertaining the existence of the facts necessary to the correct application of a law (Posner, 2001; Shavell, 1993; Shavell, 2004). Namely, the law's deterrent effect is weakened if enforced without regard to whether the "circumstances are those to which the law was intended to apply" (Posner, 2011).

Saying all that, it has to be emphasized that the absence of the rule of law will result in a society riven by clientelism, opportunism, moral hazard, clannishness, nepotism, adverse selection, social injustice and bribery.

The rule of law is in fact also crucial to all dimensions of sustainable development and the implementation of sustainable practices throughout societies and countries. Namely, by ensuring stable, transparent legal regimes (law-making and enforcement), the rule of law promotes sustainable economic development and, by ensuring equal opportunities and access to services, it also promotes social and human development (Khan, 2018). By strengthening the legal framework to protect the environment (i.e. addressing the problem of negative externalities) and ensuring the fair, sustainable management of scarce resources, the rule of law protects our planet as well (Khan, 2018). The World's Justice Project's Rule of Law Index shows that the quality of the rule of law in a country correlates both with its economic success and its GDP. Conversely, states with a weak rule of law have lower levels of prosperity and social wealth.

In this respect, the literature defines rule of law as a system of rules and institutions that constrain the arbitrary use of power (Trebilcock and Prado, 2011; Khan, 2018). Moreover, for a legal regime to be effective laws must be clear and capable of being followed (Khan, 2018). Still, the legal fabric required to achieve the desired outcomes includes not simply the creation of obligations and rights, but also their independent, impartial judicial implementation and enforcement (Ogus, 2006). 
However, the rule of law does not materialize automatically and without constant effort (step-by-step) and maintenance it cannot continue to exist. As Justice Breyer from the US Supreme Court once stated: "following the law is a matter of custom, of habit, of widely shared understandings as to how those in government and members of the public should act when faced with a court decision they strongly dislike... that habit and widely shared understanding cannot be achieved without a struggle; it is a long gradual development based on experience" (Breyer, 2011).

The operation of the rule of law also requires time, integrity, constant commitment and even in a democracy it is not self-evident (Corstens, 2017). It is not a "binary concept, one or zero, a case of all or nothing, but instead exists in various degrees of quality" (Corstens, 2017). Recently, Brazil has witnessed acts by its government that have undermined both the rule of law and democracy. For example, in 2020, Jair Messias Bolsonaro, the 38th president of Brazil, at a demonstration argued in favour of the military dictatorship that had defended the closure of the National Congress. The Federative Republic of Brazil also violated its obligations under Article 4 (right to life) and Article 5 (right to personal integrity) of the Federal Constitution in episodes like the prison massacres (Massacre nas Prisões, 2017), the Osasco Slaughter (Chacina de Osasco, 2006) and the Carandiru Massacre (Massacre do Carandiru, 1992). The separation of powers created by the 1988 Constitution and established in Article 60, \4, III, of the Magna Law (Magna Carta Magna) is also not being complied with.

In a recent episode, the Supreme Federal Court (Supremo Tribunal Federal) through Direct Action of Unconstitutionality 3112 (Ação Direta de Inconstitucionalidade 3112) disrespected the rule of law and ignored the competencies of the legislative power given by the Disarmament Statute, Law 10.826/03 (Estatuto do Desarmamento, Lei 10.826 / 03), which establishes that the illegal possession of a weapon would no longer be a felony crime. The non-alignment of the sources of law also creates regulatory confusion. While concubinage is foreseen by Article 1727 of the Civil Code (Código civil), the Brazilian jurisprudence still fails to recognition of a family entity, disrespecting the democratic principle. Obviously, all such practices are directly in breach of the rule of law and in the long term also undermine economic growth and prosperity. 
Greenspan observed that the "rule of law and property rights appear to me to be the most prominent institutional pillars of economic growth and prosperity" (Greenspan, 2007). Therefore, a strong rule of law is also the most important institutional pillar enabling the effective implementation of the agenda for sustainability and its goals. In the absence of a strong (quality) rule of law, the longrun implementation of sustainability goals will be futile and unsuccessful.

\section{Social injustice and violence in Brazil}

This section offers our conceptual framework that helps explain the current social injustice and violence that is rampant in Brazil from the perspective of the interrelationship between a history that was born in inequality and the long-term consequences for public security and violence. The systematic structural imbalance of the Brazilian State, in place since it was formed, legitimises differences in citizens' social and economic spheres. It also leads to a high level of civil and State violence aimed primarily at a specific part of the population: the descendants of the enslaved. As a result of what might be called this "targeted" discrimination, society as a whole is exposed to a level of crime that degrades the quality of life across the country, and not only to those enclaves where the targeted population reside. Moreover, discussed patterns of social injustice and violence trajectories in Brazil will be, as suggested in Chapter 2, a direct materialization of the absence of the rule of law.

\subsection{Brazil's violent history}

Brazil has existed as a nation for more than 500 years. Its history shows that its people have been shaped by violence and exploitation. Brazil was discovered in 1500 by an error made in route calculation when Portuguese ships were aiming to reach India but by mistake eventually found the coast of Pindorama, as Brazil was called prior to the arrival of Pedro Álvares Cabral.

According to historian (Souza, 2006), the colonisation had no consistent concern with settlement at the start, and Portugal, which prioritised the East, considered the land, still a fragmented territory, as some kind of "security space" for later activities. The early colonisation did not ensure unity and several colonising fronts were established with independent and isolated characteristics, while lacking in communication among each other. 
Moog (1964) compared the colonisation of Brazil and the United States, which occurred at similar times, showing that while in the USA most settlers were pilgrims who came to settle with their family in the new world, to follow their faith and cultivate their piece of land, in Brazil explorers came to explore the forests to capture the Indians to do slave labour and obtain riches like gold and precious stones for trade with Europe.

Without intending to settle in the country to live for any considerable time, due to travel fatigue eventually many explorers established small villages in the midst of their expeditions, leading to the first cities, without any organisation and intention, causing future problems in the infrastructure of cities that developed without any planning and only as extraction-facilitating resources.

Due to the early exploitation, the main characteristics of Brazil included an emergent miscegenation (many indigenous women were raped to 'satisfice' the explorers' sexual needs), income concentration, a high index of indigenous death (for the battles that occurred between them and the Portuguese explorers). Later on, the Catholic Church arrived in this new land and with the incredible power it then possessed put pressure on the empire to not use the indigenous population as slaves; they were a propitious people to become new Christians. To compensate for the absence of slaves, the empire decided to start purchasing African slaves and, as Calligaris (1991: 16-18) writes:

[...] the colonizer was the one who came to impose his tongue on a new land, that is, at the same time to demonstrate the paternal power (the father's tongue will know how to make another body other than the maternal body) and will exercise it away from dad. For perbaps the father only bans the motherland's body and here, far from him, its inherited and exported power opens access to a body that the father did not forbid. He wields the new earth as one can shake the body of a possessed woman, shouting: Enjoys Brazil, awaiting the very enjoyment of the moment when the exhausted woman will fade into your hands - definitive proof of the rapist's potency.

As noted, the natives living here were also the target of greed and violence by the colonisers, seen to this day through the prism of the scant importance of this segment of the population and the genocide of entire nations of natives. This struggle for the rights of Brazil's first inhabitants is still going on today. Another 
facet of Brazil as a colony in relation to violence was the replacement, for slavery, of indigenous labour by the labour of African slaves.

Social and institutional racism in the country arises from this time (when the black population was not even considered to be human in the colonisers' eyes, merely as instruments of work, as the property of white men, without rights, opinions or appropriate living conditions) and continues in disguised form even today, in the shape of the huge economic and social differences between black and white individuals. This racism has had and continues to have a direct influence on the current violence seen in the country, with a large black prison population and a high death toll among young people of African descent. This violence is these days aggravated by the serious problem of drug trafficking, drastically affecting the country's poorest areas, such as the well-known "favelas".

The Brazilian economy in this period was a slave economy, with abolition only coming in 1888, the latest occidental nation to abolish slavery, exclusively due to the pressure applied by the USA and the British Commonwealth that were seeking new markets for their products (the abolition of slavery meant more consumers of their products). There were no intentions on the part of those then governing society to give the Afro descendants any freedom and much less to provide for their inclusion in society, triggering a range of new free men who had not the slightest education, no patrimony, no home to live in, suffering from widespread racism and working for meagre exchanges since they accepted any kind of payment, even food. It is these low wages that allow a slave to find a place to live, in neighbourhoods distant from the centre, that is, in peripheral regions.

Shops, basements, tenements and shacks built on city outskirts then become alternatives the slave found to build a personal living space regardless of whether he could properly control it.

In addition, the slaves were then given the opportunity to manage their own time and work rhythm, also allowing those with the same ethnic and cultural origins to be reunified (Gomes, 1990: 10). 
As Brazilian cities developed, different areas within them began to have colour and social class. The central neighbourhoods had very high values and were occupied by white people in contrast to the peripheral neighbourhoods that were occupied illegally by black people. According to Carril (2006: 17), "Study on the growth of the city of São Paulo shows how the population grew darker as it moved toward the periphery". This was the key moment when social disparities exploded and is one of the biggest reasons for the current social and economic inequality in the country.

\section{$3 \quad$ Social inequality and violence}

While analysing data on the most dangerous countries or regions in the world, it is easy to trace the connection of violence with especially developing countries where the socio-economic inequalities are clearer. These inequalities are a "manifestation of an unequal distribution of resources socially, economically and politically" (Wood and Carvalho, 1988; Carvalho, 1997). Given the undeveloped research into this relationship, a comparative parallel among violence and development will be made based on available data. According to the United Nations (2020), Central and South America are the most violent regions on the globe, with 20 countries found on the list of the world's 25 most violent countries. As Mexico is also present in 20 th place on the list, Latin America may be classified as the global region with the highest concentration of violence in the world, followed by the African continent.

It is necessary to understand that almost all countries in Latin America underwent the explorative and violent process of colonisation and today carry considerable baggage of huge socio-economic inequalities, partly due to the heritage of the years spent as colonies. With the advent of modernity, cities started to grow and develop but were unable to combat the inequalities that have intensified over time and have fuelled ever greater violence.

The results of the Gini coefficient reveal that only countries from Latin America and Africa hold the top 10 positions of unequal countries. Regions with a higher coefficient of inequalities, as are common in Latin America and Africa, are also those with a higher incidence of crimes and less public safety. These two results lead to a third one: Violence is observed more in developing countries that also have a higher index for socio-economic inequality. 
Brazil is no exception and has a high index of inequality, with IBGE (Instituto Brasileiro de Geografia e Pesquisa) conducting surveys which reveal that the concentration of income in the country is appalling: The average income of the richest one percent of the Brazilian population is 33.8 times the level of the poorest 50 percent. A parallel index of social development, and the incidence of crime in various city neighbourhoods in Curitiba, reveals the negative relationship between these two variables which may be seen on the graph provided in 2017 by Mônica Máximo da Silva from the Curitiba Urban Research and Planning Institute (Instituto de Pesquisa e Planejamento Urbano de Curitiba) and the co-authors Luiza Alberti Torrens, Maria Clara Iura Schafaschek and Vinicius Luigi Miozzo.

The statistical data also allow the identification of a negative relationship between social development and crime. The most socially developed regions were those that performed worst in the area of crime against the person. The same pattern may be identified across Brazil as a whole, with the less social developed population facing a high index of violence against the person.

The low socially developed Brazilian population is largely concentrated in the favelas and is the most affected by violence. Consistent with this, most of the Brazilian prison population is black and poor, which is not surprising because as mentioned the poor Brazilian population has a colour: the black population living in the slums.

With public assistance lacking, needs that should be met by the state are not and much of the population must resort to the private sphere. Such cases are seen in areas like health, education and transportation. The discrepancy in these systems is clear and enormous: whereas the private side is advanced and praised internationally, the public side lives amid the chaos of inefficient assistance policies. Unfortunately, the poorest people in the country cannot afford to rely on the private system and are hence at the mercy of the failed system. Thus, access to education, for example, is precarious and inefficient, resulting in a lack of education for the population and consequently a lack of opportunities for social and economic change. This lack of opportunity is a factor driving people into the world of crime. Young people without any prospect of social improvement regard crime as a way to survive. This reality has become so widespread that trafficking, explained in the next section, is considered normal. 
Within sociology, it is commonly agreed that the environment influences behaviour in society since humans are social beings. The initial mirror of a human being's behaviour is the family, which is also where the first human contact takes place, followed by relationships established with others through friendship. This interaction shapes human thinking about what is right and normal. Thus, a child born in a violent environment, with his father involved in trafficking and having witnessed deaths in childhood, associates this reality with something normal that should be copied. Even if later in life this child develops the critical sense that violent action is wrong, it often is impossible for such a person to escape the criminal world because, once entered, many leave only when dead (typically through violence), a phrase uttered by criminal gang leaders.

The unreliability of the police is another influence that perpetuates the existence of criminal groups in low-income environments. Police in Brazil function poorly as they are not well trained. Brazilian police have the dubious distinction of not only killing but also dying the most. The constant clashes between the police and criminals in the favelas produce a considerable number of stray bullet deaths, leading the non-criminal population in that environment to often support the "bad guy" and loathe the police. Obviously, this absence of the rule of law has resulted in a society riven by clientelism, opportunism, moral hazard, clannishness, nepotism, adverse selection, social injustice and bribery.

Political violence, incarceration and its detrimental effect on development: towards mass social injustice

\subsection{Punitive System, Criminal Policies and Mass Incarceration}

There have been two periods of dictatorship in the history of the Federative Republic of Brazil. The first was from 1937-1945, and involved the dictatorship of Getúlio Vargas called "Estado Novo." and the second was from 1964-1985, and involved the military dictatorship (Ditadura Militar), that initially came to protect the country from the threat of communists. In these two periods, dictators held broad powers, suppressed freedom, violently repressed opponents, and had limited legislative and judicial powers. In the Vargas Era, the National Congress and Legislative Assemblies were closed, with Article 37 of the Constitution of 1937 declaring the President the Supreme Authority: 
"The President of the Republic, the supreme authority of the State, coordinates the activity of the representative bodies, of superior degree, directs the internal and external policy, promotes or guides the legislative policy of national interest, and oversees the administration of the country" (Constitution of the Federative Republic of Brazil, 1937: Article 73).

In 1939, Getulio Vargas created the Department of Press and Propaganda which censored communication. As an instrument of censorship, it aimed for the ideological control of society, promoting advertisements about the political regime, and blocking criticism. The Military Dictatorship was marked by 17 Institutional Acts (Atos Institucionais) - legal diplomas issued by the executive - that implemented censorship, the suppression of constitutional rights, political persecution, and the repression of those who opposed the military regime. Devoid of legal authority, AI-5 (Institutional Act 5) is considered the most repressive of the period. Published in 1968, the decree reinforced censorship and torture as standard government practices. It also prohibited public demonstrations, allowed the president to decree the closure of the national congress, the suspension of political rights and the restriction of any public or private right.

After the second dictatorship period had come to an end, a "re-democratisation period" commenced with the introduction of a new Constitution that would guarantee rights to all citizens. According to Alessandra Teixeira (2006), this process of re-democratising the country gave way to an ephemeral period of "politicisation" of the prison issue that would support the progressive criminal normative, the reform of the Penal Code (Código penal) and the first Law of Penal Executions (Lei de Execução Penal). These legal instruments enshrined conceptions of a less repressive criminal policy, centred on the reintegrating character of prison and an extensive list of rights that were unpublished and ascribed both to accused and convicted individuals. This was the first time in the country's history that civil rights had been discussed with respect to all spheres.

These legal instruments activated mechanisms opposed to mass incarceration and were triggered by an alternative penal system and the effective progressivity of the penal regimes, as well as the autonomy of criminal execution. This last point would translate to the choice of the jurisdictional model in the execution of the penalty, meaning at that moment the perspective of the insertion of the individual arrested in a legal order, granting the individual the "status" of a subject of rights afforded 
with protection. For example, Article 6 of the Law of Penal Executions provides that "the classification will be made by the Technical Classification Commission that will elaborate the individualizing program and will monitor the execution of the deprivation of liberty and the restriction of rights, and must propose to the competent authority the progressions and regressions of the regimes, as well as the conversions" (Law of Penal Executions - Lei de Execução penal, 1984: Article 6).

Through the humanisation policy of the prisons promoted by then secretary of justice José Carlos Dias during the elected government of Franco Montoro in the State of São Paulo (1983-1986), he gave effect to the individual rights of prisoners - legal assistance, expansion of measures to minimize overcrowding of the prisons, interventions aimed at containing tensions within the system such as allowing intimate visits for male prisoners - and foresaw the creation of mechanisms also capable of giving prisoners a political existence.

Accordingly, measures such as the creation of Solidarity Commissions (Comissões de Solidariedade) - committees of directly elected prisoners - and the installation of ballot boxes in prisons gave prisoners the possibility (explicitly denied in prison) of speech, the right to a voice, in an important subversion of prison existence hardly paralleled in history. Such mechanisms provided true channels of representation and direct interlocution between the prisoner, the authorities and society in general, without the mediation and restrictions of disciplinary power.

The lack of information - concerning the positive effect of democratic measures in prisons for the reduction of social violence - aligned with the existing structural prejudice with those who pass through the system, forms the concept that prevails in the current sphere; that a prisoner should not have the same rights as a free citizen, after all, he abdicated this privilege when committing the offence or infraction. However, in practice, what is observed is the rebound that non-democratic measures bring; it generates even more violence for all, free or imprisoned citizens.

A smarter strategy would be to reintegrate prisoners into society and provide opportunities to those who never had them. After all, the environment in which we operate shapes much of our thoughts and actions. Following Howard Becker's thinking, prisoners are outsiders to those who are not in the prison system because they have broken a law described in the country's penal code. Yet, perhaps from the prisoner's perspective, the population outside the gaol is the group that does not 
adhere to the legislation since the laws enumerated in the penal code do not permeate and are not applied in the community where the outsider was raised, while the commonly accepted mores in that environment are those imposed by a group apart from the country's legislators.

Implementing educational and reintegration policies for prisoners in the community, as opposed to utilizing a strictly punitive system, reduce the possibility of recidivism. On the other hand, a state that engages in purely punitive politics encourages recidivism as such policies inevitably leave the prisoner with little choice but to return to crime after release, either due to financial strains, or, by having been abused in the system does not view the law as a solution but instead as the problem.

Unfortunately, both politicians and a large segment of society could not leave their own preconceptions to the side and a new criminal policy was then implemented that is especially based on repression and institutional abuse. In 1986, a "security package" consisting of "tough" measures to combat violence was launched. Its implementation in 1987 represented the rise and prevalence of a public security ideology explicitly grounded in human rights violations. From the conservative element of Brazil's point of view, policies of repression of crime led to the dismantling of the newly constructed legal framework of individual guarantees, particularly regarding those who are accused and those convicted. Provisions of the Law of Penal Executions were rewritten in line with the new mentality, stating that "the classification will be made by the Technical Classification Commission that will elaborate the individualizing program of the deprivation of liberty adequate to the condemned or provisional prisoner" (Law of Penal Executions - Lei de Execução Penal, 2003: Article 6).

The period was also characterised by increased violence, especially in the urban environment - both state violence (with the worsening of human rights violations, uncontrolled police actions, torture, etc.) and the increase in violent crime observed since the 1980s, especially in large cities. At the prison level, human rights defence policies were abandoned. These policies led to episodes of prisoners being physically abused and sometimes killed, along with a lack of enthusiasm to provide prison facilities with even minimally viable physical conditions for the custody of detainees. The period was further marked by greater violence within disciplinary practices. Earlier criminal articles have become increasingly rigid and incisive, as may be seen in Article 52 of the Law of Penal Executions first established in 1984 and amended 
in both 2003 and 2019. The law, which establishes that extra-disciplinary sanctions, previously only applied to a convict or prisoner who commits a felony, was extended to cases of subversion of internal order or discipline in 2003 (Martins, 2016). In 2019, the text was redrafted to further intensify the rigidity of the provisions, establishing a maximum period of disciplinary sanction of 2 years (previously 1 year).

The prisoners started to be placed in heterogeneous units, which brought many apparent masters of certain crimes together. The terrible institutional conditions were conducive of the formation of feelings of common injustice and forms of mutual support and resistance among inmates (Goffman, 1996). The inmates also included in their ranks political prisoners with whom other inmates learned guerrilla and organisational techniques. The gathering of criminals including the most "dangerous" and "undisciplined" in the same establishment and their later dispersal across the prison system in places where their range of action and power of mobilisation were multiplied were the key reasons that contributed to the formation of the militias that have come to dominate crime in Brazil's prisons and beyond (Portella, 2018).

With Brazil's subsequent advent as a cocaine route to Europe, the militias set up a drug trafficking scheme especially in the favelas, a region forgotten by public policy and the state. In this way, once the area was forgotten by the state, crime in this region rose exponentially and the economy became drug-based, known for high criminality and easy access to guns. By this time, the militias had created an arsenal of imported weapons more powerful than even those possessed by state agents, making the fight against crime exceedingly difficult.

As already emphasised, the population's support for criminal factions and the reluctant movement against the police, which is unprepared and relies on abuse of violence, is another explanation of why the declared war against crime is so hard to win.

\subsection{Mass incarceration and economic effects}

As argued previously in chapter 2, the absence of the rule of law and subsequent explosion of transaction costs will sooner or later result in a society riven by clientelism, opportunism, moral hazard, clannishness, nepotism, adverse selection, social injustice and bribery. As circumstantial evidence for that claim we offer an 
example of mass incarceration in Brazil. The high level of criminality and the punitive policies of repression have seen the number of prisoners in Brazil reach the massive number of over 800,000 . This phenomenon is called mass incarceration. The mass incarceration was exacerbated by the intensification of punitive measures which led to longer sentences, causing more prisoners to accumulate at the same time in the prison complex. Namely, Article 112 of the Law of Penal Executions (1984) was rewritten limiting the potential for social development of imprisoned population.

The overcrowding of prisons, combined with the lack of human living conditions, make incarceration in Brazil a school for crime. Criminals enter the system and leave worse than when they arrived, and with high levels of recidivism, and, according to statistical data, committing even more serious crimes. The lack of a reintegration policy in society, coupled with the idea that the prison system should only be punitive, has resulted in a situation where it is extraordinarily difficult for released inmates to integrate into society as productive members. It is also possible to use the term "waste" to describe this unfortunate situation. According to Dubois et al. (2009), the usefulness of this large segment of the population is being squandered, or wasted, because they are not making contributions to society either while incarcerated or upon their reintroduction into society. They then become a net drain on society, often being unable to hold gainful employment, living a life of crime, and often committing more aggravated crimes than the ones they were initially imprisoned for, and then predictably landing back in a foul prison system that repeats this story over and over.

As Schmidtz (2009) warns, there is also the "collateral cost" associated with such a dysfunctional penal system. Part of the cost of this system is the impact it has on viewers. In this case, the spectators are the people outside of the prison system, both those who pay taxes because the portion that is allocated to the prison system is not paid as welfare to society, and also to those who are not yet taxpayers but miss the opportunity for these taxes to be invested in areas that would actually bring a positive return to society. Brazil's flawed criminal system is costly. Policies should be instituted that focus on rehabilitating inmates so, once released from prison, they can be successfully reintegrated into society. Such policies not only would benefit the prior inmate, directing him away from a former life of crime, into a working useful member of society, but obviously benefits society as a whole as this person might eventually become an active taxpayer that adds to, not subtracts from, the 
economy. History has unfortunately shown that the absence of such forwardthinking, proactive policies are in the end short-sighted and lead only to recidivist behaviours, to the detriment (and great expense) of all concerned.

In terms of numbers, a study by the Inter-American Development Bank (IDB) shows that the cost of crime and violence in Brazil was USD 91.38 billion in 2014, or 3.78 percent of that year's GDP. The cost of crime should not be confused with the cost of incarceration, even if one is associated with the other. At the same time, Brazil spends around $\mathrm{R} \$ 40,000$ per prisoner a year, amounting to approximately EUR 6.4 billion per year. Yet, in contradiction, at the same time the government spends R $\$ 15,000$ per student, namely almost three times less. Studies conducted at the University of São Paulo (USP) show that for every one percent more invested in education there is a 0.1 percent decrease in crime rates.

Ferreira states that "it is often said that incarceration is a costly activity only in Brazil. In fact, the prison system is especially expensive in underdeveloped or developing countries, where the prison population is high due to the imprisonment trap, which is part of the culture of the repressive organs of these countries, with direct effects on the economy" (Ferreira, 2018: 15). Thus, as already explained in Chapter 2, this costly, unsophisticated and unequal legal system ends up bringing costs beyond the criminal sphere, and together with the transactional cost, they contribute to social injustice, inequality and poverty.

\section{$5 \quad$ Towards an improved institutional framework in Brasil}

Mass incarceration, social inequality and violence are factors that go hand in hand. Thus, there is no point in remedying only one of these factors in isolation. Instead, all of them must be addressed in parallel. In theory, they could be treated individually, but attacking the situation piecemeal would take decades to have some practical effect on society and improve the rule of law in Brazil. Thus, we propose the following measures as a way to alleviate and treat the errors and deficiencies of the Brazilian system: a) massive incarceration should be stopped; b) investment in inclusive policies and systematic implementation of the rule of law principles throughout the society should became a governmental priority; and c) there should be substantial changes in the tax system. Each of these proposals are analysed in more detail in the next sub sections. 


\subsection{Estopping massive incarceration}

Mass incarceration can be considered a "school of crime", or at least an incentive to continue living in crime. What should be used as a last resort for punishment, ended up being trivialized in the Brazilian system and instead became a central punishment measure. Furthermore, the war on crime policy of increasing arrests and incarcerating more has not only lessened crime it has increased it. To reverse this counterproductive trend, Brazil must urgently adopt policies that will stop overcrowding the prison population. According to the National Council of Justice, 41.5 percent of the prison population is made up of preventive prisoners (still without trial). Thus, allowing persons accused of lesser crimes to remain free pending trial is an effective (and much less expensive) way of reducing overcrowding in prisons.

Still related to the previous theme, the decrease in the preventive population in prison would open space for the remaining pre-trial detainees to be separated from those convicted. What is more, the condemned could be separated by degree of danger. In theory, this is already provided for by law, but it is not done in practice due to overcrowding in criminal units. Failure to separate these prisoners is a precondition for primary or low-risk convicts to be included in the criminal cycle, a conundrum that is difficult to break.

Another limiting factor is that, according to the Brazilian Penal Code, alternative penalties (i.e. day fines, community service probation) to imprisonment can only be applied to convictions of less than four years. Even so, in practice, alternative penalties are rarely used for drug trafficking cases (a crime of greater contingency in prison), which makes the likelihood of their application trivial and encourages incarceration. Changing such legislation to a more comprehensive one would facilitate the prevention of contact between low-risk criminals and major criminal factions. As a consequence, the vicious cycle of incarceration and crime could be lessened.

Mass incarceration needs to terminate. This practice has been a failure, to the detriment of both the inmates and society at large. Incarceration, as a means of punishment, should be the last resort, not the first, as it has been. 


\subsection{Investments in inclusive policies and rule of law capacity building}

It is useless to change the Brazilian criminal policy if the society itself is at least partly responsible for the deviant behaviour of the citizen. Therefore, even if alternative penalties are imposed, and there is a decrease in contact between low-risk and highrisk prisoners, the very environment into which they are inserted will be responsible for recidivism. Clearly, the individual must accept culpability and responsibility for the criminal act engaged in. However, it is undeniable that the environment and culture directly influence the individual's behaviour and decisions. A preventive and resocializing prison system will fail to be effective unless the convict's social structure of coexistence is aligned. Thus, public policies must allow even the most marginalized members of society access to social and labour market opportunities to short-circuit the cycle of poverty and crime. The principal driver to break this vicious cycle is education. Although investment in education does not yield immediate results, over the long term it unquestionably is the most effective solution for reducing social inequality and crime. Thus, public investment in quality education (from primary school to university), significantly increases the chances that an individual will not participate in crime. While increased investment in the public education system will pay substantial long-term dividends, the question remains how to best deal with older individuals and those individuals that currently are in the criminal justice system that never received an adequate education.

A viable option is to create an educational quota system. Contrary to what happens today, this system must be subjected to a maximum usage time, since it has become a way for politicians to obtain more population votes. Thus, politicians stop investing effectively in basic education and start to establish racial and economic quotas, which have no concrete and long-term effect on society. It is necessary that allied to these quotas there is an extensive investment in the educational structure so that effective results can be achieved.

In addition, Brazil must take greater public measures to support employability. In a country where the fiscal deficit is huge, it is not easy to talk about more spending on public works to generate employment. Thus, a viable option is a realization of public, private partnerships (hereinafter: PPP), which are already successful in other areas such as health. PPP calls can be conducted to generate both quality service and employment. In this way, partnerships between municipal, state and federal governments with private companies could establish a tax reduction if a certain 
percentage of workers from a certain region are hired (which in this case should be a place with a shortage of job opportunities). Such schemes would not only help bolster employment in high risk areas but would also strengthen governmental relationships with private companies, benefit the economy and reduce transaction costs. For example, the US city of Pittsburgh might be employed as a success story. Namely, the local government came up with the idea that any person finishing high school could automatically go to a local university/college and it would be paid for. This in turn led to a high number of young persons that became qualified for work, boosted productive members of society; increased human capital; lowered transaction costs; local businesses had a ready work force; and the overall social wealth has been increased.

Moreover, substantial investments have to be allocated to the systematic improvements of the governing principles of the rule of law discussed above. Strengthening the rule of law is a necessary precondition for the operation of the system of economic exchanges, and is critical for the prosperity of markets, consequent economic progress, social justice and related decrease of poverty. Conversely, the absence of the rule of law will continue to result in a society riven by clientelism, opportunism, moral hazard, clannishness, nepotism, adverse selection, social injustice and bribery. The rule of law is bedrock principle crucial to all dimensions of Brazilian development and to the implementation of sustainable practices throughout the entire country. Namely, by ensuring stable, transparent legal regimes (law-making and enforcement), the rule of law will promote sustainable economic development in Brazil and, by ensuring equal opportunities and access to services, it also promotes social and human development.

\subsection{Changes in the tax system}

The objective of the current Brazilian tax system is to reduce social and economic inequalities through the concept of redistribution. However, in practice, this does not occur. Instead, it creates even more inequalities and places the economic burden on the poorest people. This aspect is perhaps the most painful to Brazilian society and violates two fundamental principles: the Principle of Isonomy, present in the federal constitution, and the Principle of Contributory Capacity, present specifically in tax law. According to the first principle, equals must be treated equally and unequal ones unequally, in order to create social equality. Moreover, according to the second, taxes must be computed for each individual according to their financial 
capacity. In practice, a large part of Brazilian tax is generated from taxes on labour and especially on consumption, and not on capital and equity income. In other words, tax revenue is largely derived from the sale and purchase of essential products, such as food and hygiene products.

This means that in practice when buying essential items, the tax rate disproportionately impacts the poorest members of the society, as they are forced to spend a much higher percentage of their salary on taxes compared to the rich, thereby creating even more economic and social inequality. Imagine, therefore, that a large part of the population receives a minimum wage, which is equivalent to 159.94 euros, or even less if they are informal workers. Imagine also that the minimum salary of a state law judge is 4000.63 euros, and these two groups of people have the same basic food needs. The tax paid by the poor for a bag of rice (that costs at the moment around 6.13 euros) is equivalent to 3.8 percent of the minimum wage, while for the hypothetical judge in Brazil this is equivalent to just 0.15 percent.

Despite its theoretical distributive function, two-thirds of national taxes are levied not on income (where the country has a proportional system), but on consumption, which includes basic food, hygiene and health products. Meanwhile, direct taxes on income and property (IPTU, ITR, IR, IPVA, ITBI, ITCD) correspond to 8.2 percent of GDP or 24.0 percent of the total load. In addition to the problem of indirect taxation being the most prevalent in the country, the study by the Economic and Social Development Council shows that IR (income tax), the most important direct tax for income redistribution, is poorly organized and used in Brazil. Its degree of progressivity, referring to individuals, depends on the number of income brackets, on which the tax rates are applied, from the exemption to the maximum taxation. Over time, the number of bands and the percentage of aliquots has regressed, and at the same time, social inequalities have increased. In the years 1983 - 1985, Brazil had 13 income brackets and rates ranging from 0 to 60 percent, with five percent intervals. Currently, however, the country has aliquots of 0 percent, 7.5 percent, 15.0 percent, 22.5 percent and 27.5 percent. The maximum Brazilian tax rate is still far below most countries. In this way, it can be concluded that the taxes are clearly disproportionate on the poorest and the richest.

"The National Tax System has not fulfilled its redistributive function. On the contrary, it has always been a bighly regressive and income-concentrating system. Taxation in Brazil mainly burdens labour and consumption, while the capital 
and equity income are not taxed according to the capacity of their holders. Contrary to developed countries where most of the collection comes from taxes on income and wealth, in Brazil, about two-thirds of taxes come from taxation on consumption, even from products destined basic survival, such as food, medicine and personal care products". (Fattorelli Carneiro, UNAFISCO NACIONAL, 2010).

Additionally, the fact that the tax also weighs heavily on labour, companies have little incentive to do business in the country. This fact thwarts, rather than encourages, new business and entrepreneurship. Those businesses that remain in Brazil tend to fire several employees since the cost of having the employee becomes extreme due to the fees applied. This increases unemployment in Brazil, causes economic retraction, and since the problem has gone unchecked, has led to a continued downward economic spiral. This conundrum has served to encourage criminal activity. Brazil's high unemployment rate, especially among poor young people living in precarious situations, has forced these marginalized people into a life of performing illegal work and activities, especially drug trafficking. According to the National Registry of Adolescents in conflict with the Law and the National Registry of Justice, about 192,000 adolescents in 2017 were arrested for drug trafficking.

Contrary to its main objective, the tax system is the most significant income concentrator in Brazil and is a direct contributor to the difficulties that the country faces. The system increases production costs, increases commodity prices, discourages employment and compromises competitiveness in Brazil, as well as internationally.

For these reasons, changes in the tax system are imperative. The primary reform should be to make direct taxation - in particular income taxation - the greatest source of tax collection. Additionally, the tax rate on the highest income earners must be raised from 27.5 percent. These changes will help facilitate and promote one of the objectives of taxation (reduce inequality), and will additionally encourage employment and reduce transaction costs. 


\section{Conclusion}

"No one who has been thinking about history and politics can remain oblivious to the enormous role that violence has always played" (Arendt, 1970).

Violence and social inequality are factors embedded in the formation of the Democratic State of Brazil, having been inherited from its colonial days. The social and economic consequences of this are apparent today, evidenced not only by a high concentration of wealth for top income earners but also the asymmetry that exists in social opportunities between the relatively few rich and the balance of the population. This structural inequality intensifies the level of crime which is being ineffectively combated in Brazil, since state policies of high repression and little attention devoted to creating opportunities and re-socialisation for the lawbreakers has served only to further increase poverty and criminal activities.

In this way, the Brazilian State via its excessively punitive criminal justice policies and its weak rule of law is the driving force in its prisons serving only to reinforce criminal norms among its inmates, instead of rehabilitating them, and therefore indirectly provides incentives for prisoners to return to their unlawful ways upon release from prison. The State is also failing in its role as a Welfare State. It does not offer quality essential public services, in turn hampering the performance of citizens and creating environments even more conducive to crime. The economically disadvantaged portion of the population is becoming invisible to the State (out of sight out of mind) and only functions to proliferate violence. Brazil's history is a textbook case of a country of inherited violence, social inequality and inefficient public management, perpetuated and even exacerbated by poor educational policies, a poor criminal justice system and unfair taxation policies, which in combination have resulted in the present chaotic situation. The outcomes are seen in the economy, shaped by the intense colours of inequality, violence and crime. Once these narratives become dependent on each other (as they currently are), all of the underlying causes must be must be reformed in tandem for the situation to be reversed. Addressing any one of the problems, to the exclusion of others, will only lead to failure, which means additional insecurity, fear and a lack of opportunities for a majority of the population. Investment in education which, as mentioned, has a direct correlation to lowering the crime rate, must be aligned with the creation of a new, less repressive and more permissive punitive policy that would discourage released inmates from returning to a life of crime. Moreover, the application of these 
new policies must be carried out according to the broad rule of law and human rights principles. To reduce social inequalities, apart from a significant investment in education, the State must play a more active role in the social sphere. After reforming the present tax structure, so that it is not so regressive, and so the very wealthy shoulder a greater tax burden as a means of redistributing wealth, the State must make significantly greater investments in public services with tax receipts. Further, considerable investments also must be made in cultural activities. The mentality deeply rooted in Brazilian culture that created structural inequality must be combated in order to achieve a more just and equal society. As mentality changes, one positive development can lead to another as part of what might be called a domino effect. That is to say, the adoption and institution of one of these policies causes a positive impact on the others. Changes in governmental policies and social attitudes will not solve all of Brazil's problems overnight. Patience and a willingness to stay the course over the long haul will be required. After all, repairing difficult problems caused not only by Brazil's historical legacy but also by more recent failures in public policy will surely take time and effort. However, attacking these problems in a comprehensive way - through criminal justice reform, tax reform, education reform, public spending reforms - rather than by way of piecemeal reforms, will have a synergistic effect on Brazil's economy and social structure, and will help rectify many of the problems outlined in this paper.

\section{References}

Acemoglu, D. and Johnson, S. (2005) Unbundling Institutions, Journal of Political Economy, 113(5), pp. 949-95.

Acemoglu, D., Johnson, S., and Robinson, J. A. (2001) The Colonial Origins of Comparative Development: An Empirical Investigation, American Economic Review, 91(5), pp. 1369-1401.

Acemoglu, D., Johnson, S., and J. A. Robinson (2002) Reversal of Fortune: Geography and Institutions in the Making of the Modern World Income Distribution, Quarterly Journal of Economics, 117(4), pp. 1231-1294.

Aseeva, A. (2018) (Un)Sustainable Development(s) in International Economic Law: A Quest for Sustainability, Sustainability 10(11); pp. 4022-4052.

Arendt, H. (1970) 'On Violence,' (North Holland: Elsevier)

Arrow, J. K. and Gerard, D. (1954) Existence of an equilibrium for a competitive economy, Econometrica, 22(3), pp. 265-290.

Becker, S. G. and Richard, A. P. (2009) Uncommon Sense: Economic Insights from Marriage to Terrorism (Chicago: The University of Chicago Press).

Bouckaert, B., De Geest, G. (2009) Encyclopaedia of Law and Economics (Cheltenham: Edward Elgar).

Breyer, S. (2011) Making our democracy work, a Judge's view (New York: Alfred A. Knopf).

Calligaris, C. (1991) 'Este país não presta. In: Calligaris C. (ed.). Hello, Brasil! Notas de um psicanalista europeu viajando ao Brasil' (São Paulo: Escuta).

Carril, L. (2006) 'Quilombo, Favela e Periferia: a longa busca da cidadania' (São Paulo: Annablume). 
Carvalho, J. M (1997) 'Mandonismo, coronelismo, clientelismo: uma discussão conceitual. ' Dados, 40 (2), , pp. 1-9.

Carvalho, J. M. (1998) 'Pontos e Bordados: Escritos de história e política' (Belo Horizonte: Editora da UFMG).

Castiglione, C., Infante, D. and Smirnova, J. (2015) Environment and economic growth: is the rule of law the go-between? The case of high-income countries, 5 Energy, Sustainability and Society, $5(26)$, pp. 1-7.

Coase, R. (1937) The Nature of the Firm, Economica, 4(16), pp. 386-405.

Coase, H. R. (1960) The problem of social cost, Journal of Law and Economics, 3(1), pp. 1-44.

Coase, R. (1988) The Firm, the Market and the Law (Chicago: University of Chicago Press).

Coase, R. (1994) Essays on Economics and Economists (Chicago: University of Chicago Press).

Coase, R. (1998) The New Institutional Economics,' American Economic Review, Papers and Proceedings, 88(2), pp. 72-74.

Connolly, A. D., Tristin, M. W., and Zina, L. (2004), From Crime Control to Welfare and Back Again. In Girls and Aggression: Contributing Factors and Intervention Principles, Moretti, M. M., Candice, L. O., and Margaret, A. J. [ed.] (New York: Springer).

Cooter, D. R. and Schäfer, H. B. (2012) Solomon's Knot: How law can end the poverty of nations (New Jersey: Princeton University Press).

Corstens, G. (2017) Understanding the rule of law (London: Hart Publishing).

De Geest, G. (1994) Economische Analyse van het Contracten- en Quasi-contractenrecht' (Antwerpen, Belgium: Maklu).

De Geest, G. (2001) Comparative Law and Economics and the Design of Optimal Doctrines. V Deffains, B., Kirat, T. (ur.), Law and Economics in Civil Law Countries, 107-124, JAI Elsevier.

De Geest, G. (2011) Contract Law and Economics - Encyclopaedia of Law and Economics (Edward Elgar Cheltenham: Edward Elgar).

Delbard, O. (2008) CSR legislation in France and the European regulatory paradox: an analysis of EU CSR policy and sustainability reporting practice, Corporate Governance International Journal of Business in Society, 8(4), pp. 397-405.

Demsetz, H. (1968) 'The Cost of Transacting', Quarterly Journal of Economics, 82(1), pp. 33-53.

De Soto, H. (1989) The other path: the invisible revolution in the third world (New York: Basic Books).

Dollery, B. and Leong W.H. (1998) Measuring the Transaction Sector in the Australian Economy, 1911-1991, Australian Economic History Review, 38(1), pp. 207-231.

Dubois, A., Kulpa, L. and Souza, L. (2009) Gestão de custos e formação de preços: conceitos, modelos e instrumentos - abordagem do capital de giro e da margem de competividade (São Paulo: Atlas).

Faure, M., Smits, J. (2011) Introduction: Does Law Matter? On law and Economic Growth (Cambridge: Intersentia).

Fatorelli Carneiro, M. (2010) A Proposta de Reforma Tributária, Sindifisco Nacional.

Ferreira, C. and Santiago, N. (2018) 'O custo do encarceramento no Brasil sob a ótica da análise econômica do Direito, 'Revista Digital Constituição e garantia de Direitos, 11(1), pp. 201-216.

Goffman, E. (1996) 'Manicômios, Prisões e Conventos.' (São Paulo : Editora Perspectiva).

Gomes, L. (1990) 'Evolução da população carcerária brasileira de 1990 até 2012.‘ (Porto Allegre: Lex Magister).

Greenspan, A. (2007) 'The age of Turbulence. Adventures in a New World.' (New York: Penguin Books).

Helland, E. and J. Klick (2011), 'Legal Origins and Empirical Credibility', in M. Faure and J. Smits (eds.), Does law matter? On Law and Economic Growth, Cambridge: Intersentia.

International Development Law Organization - IDLO (2015), Doing Justice to Sustainable Development Integrating the Rule of Law into the Post-2015 Development Agenda, International Development Law Organisation.

Accessed on 12.9.2020, available at: https://www.idlo.int/sites/default/files/pdfs/Doing\%20Justice\%20to\%20Sustainable\%20D evelopment $\% 20$ report.pdf 
Kaufmann, D. (2004) Governance redux: the empirical challenge, in Xavier, S.M. (ed.), The global competitiveness report 2003-2004 (Oxford: Oxford University Press).

Khan, I. (2018), How can the rule of law advance sustainable development in a troubled and turbulent world?, McGill Journal of Sustainable Development Law, 13(2), pp. 212-218.

Kovač, M. and Spruk, R. (2016) Institutional development, transaction costs and economic growth: evidence from a cross-country investigation, Journal of institutional economics, 12(1), pp. 129159.

Martins, I. (2016) O sistema tributário brasileiro: uma análise crítica. Revista dos Tribunais, 969(1), pp. $1-45$.

Masten, S.E., Meehan, J.W. and Snyder, E.A. (1991) The Cost of Organization, Journal of Law, Economics and Organization, 7(1), 1-25.

McCloskey, D. and Klamer, A. (1995), One Quarter of GDP is Persuasion, American Economic Review, 85(2), 91-195.

Moog, V. (1964) Bandeirantes e pioneiros: paralelo entre duas culturas (Sao Paolo: Editora Globo).

North, D.C. and Wallis, J.J. (1986) Measuring the Transaction Sector in the American Economy, 18701970, NBER Chapters: Long-Term Factors in American Economic Growth, pp. 95-162.

North, D.C. (1990) Institutions, Institutional Change and Economic Performance (New York: Cambridge University Press).

North, D.C. (2005) Understanding the Process of Economic Change (New Jersey: Princeton University Press).

Ogus, A. (2006) Costs and cautionary tales: Economic insights for the law, (London: Hart Publishing).

Olson, M. (1984) The Rise and Decline of Nations: Economic Growth, Stagflation, and Social Rigidities (New Haven: Yale University Press).

Pope, J., Annandale, D. and Morrison-Saunders, A. (2004) Conceptualising sustainability assessment, Environmental Impact Assessment Review, 24(6), pp. 595-616.

Portella, A. (2018) Legislação Tributária (Sao Paolo: Universidade Federal da Bahia).

Posner, A. R. (2001) Frontiers of Legal Theory (Cambridge: Harvard University Press).

Posner, A. R (2011) Economic Analysis of Law (New York: Wolters Kluwer International).

Rawls, J. (1971) A Theory of Justice (Cambridge MA: Harvard University Press), pp. 237-239.

Rodrick, D., Subramanian, A. and Trebbi, F. (2004) Institutions rule: the primacy of institutions over geography and integration in economic development, Journal of Economic Growth, 9(2), pp. 131-165.

Rodríguez-Pose, A. (2013) Do Institutions Matter for Regional Development? Regional Studies, 47(7), pp. 1034-1047.

Schmidtz, D. (2009) Os elementos da justiça (São Paulo: WMF Martins Fontes).

Shavell, S. (1993) The optimal structure of law enforcement, The Journal of Law \& Economics, 36(1), pp. 255-287.

Shavell, S. (2004) Foundations of economic analysis of law (Cambridge: Harvard University Press).

Sobel, R. and Coyne, C. (2011) Cointegrating Institutions: The Time-Series Properties of Country Institutional Measures, Journal of Law and Economics, 54 (1), pp. 111 - 134.

Souza, L. (2006) O Sol e a Sombra. Política e administração na América portuguesa (São Paulo: Companhia das Letras).

Teixeira, A. (2006) Políticas penais no Brasil contemporâneo : uma história em três tempos L'Ordinaire des Amériques (Sao Paolo: En ligne).

Trebilcock, J. M. and Prado, M. M. (2011) What makes poor countries poor? Institutional determinants of development (Cheltenham: Edward Elgar).

Ulen, S. T. (2011) The role of law in economic growth and development, in Faure, M. and Jan, S. (ed.), Does Law Matter? On law and Economic Growth (Cambridge: Intersentia).

United Nations (2020) United Nations 2020 Global Study on Homicide (New York: United Nations).

Walker, H., Di Sisto, L. and McBain, D. (2008) Drivers and barriers to environmental supply chain management practices: lessons from the public and private sectors, Journal of Purchasing \& Supply Management, 14(1), pp. 69-85.

Williamson, O. (1996) The Mechanisms of Governance (New York: Oxford University Press). 
Wittman, D. (2006) Economic Foundation of Law and Organization (Cambridge: Cambridge University Press).

Wood, C. H. and Carvalho, J. A. M. (1988) The Demography of Inequality in Brazil (Cambridge: Cambridge University Press).

\section{About the authors}

Mitja Kovač is an Associate Professor at the University of Ljubljana School of Economics and Business.

Marcela Neves Bezerra is a researcher at the University of Ljubljana School of Economics and Business. 
